\title{
Pendidikan Agama Islam dan Pembentukan Karakter
}

\section{Faizin}

STAI Bumi Silampari Lubuklinggau

amwafaiz@gmail.com

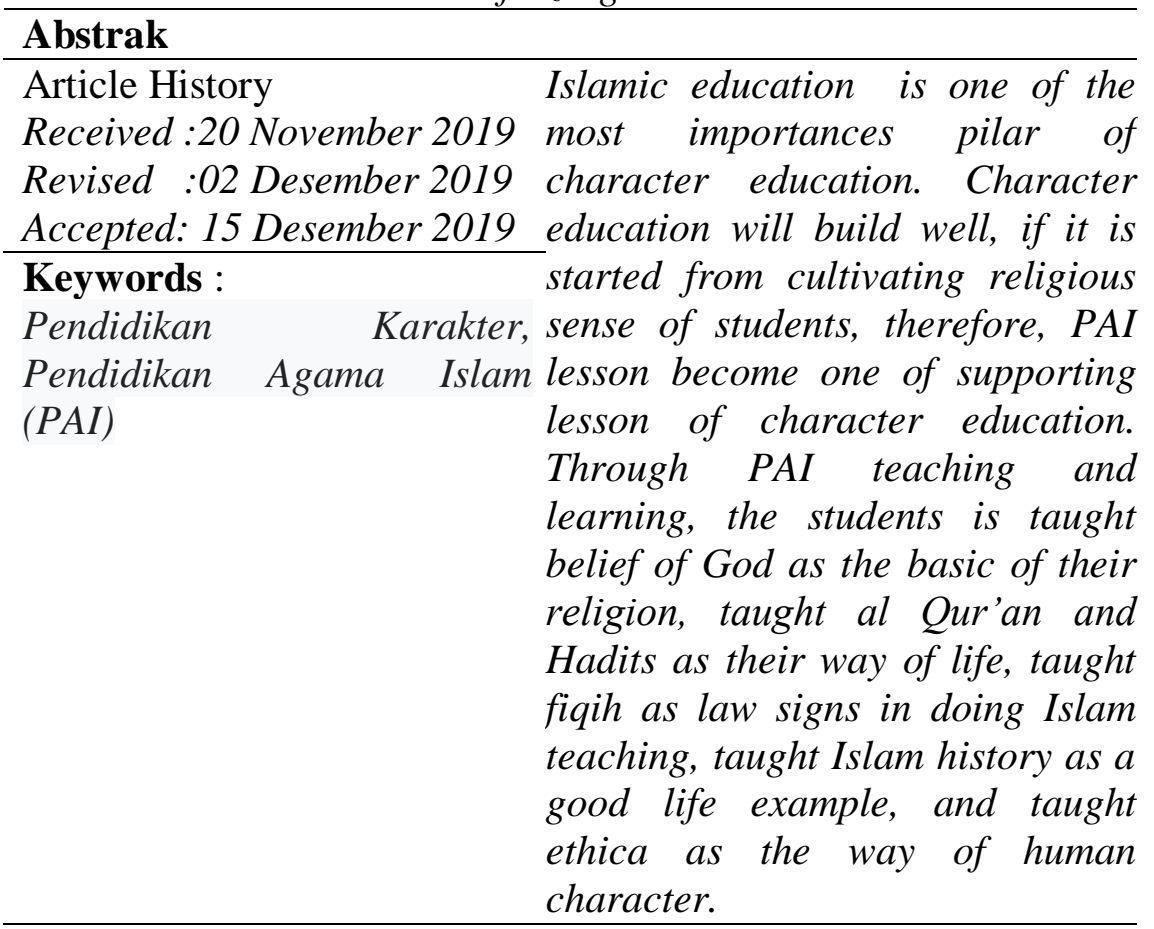

\section{Pendahuluan}

Fenomena kemerosatan moral yang terjadi di tengah-tengah masyarakat maupun di lingkungan aparatur pemerintahan, tidak terkecuali di kalangan remaja dan pelajar semakin meningkat dan beragam.Hal ini membuat pendidikan karakter menjadi isu penting.Tindak kriminal, kekerasan dalam rumah tangga (KDRT), ketidak adilan, korupsi, tawuran di kalanagn pelajar, pelangggaran HAM, menjadi bukti bahwa telah terjadi krisis jati diri dan karakteristik pada bangsa Indonesia.

Pentingnya kegiatan pendidikan karakter sangat memberi sadar dan menginginkan sistem pemberi rasa ingat untuk selalu berdiri sendiri tanpa sandaran cakupan dari pendidikan, pendidikan merupakan nilai menjadi satu kesatuan dengan cakupan tiap mata pelajaran yang ada diterapkan sekolah. Proses aturan kegiatan pendidikan karakter tidak langsung diproses melalui hasilnya waktu 
yang sangat singkat, tetapi juga membutuhkan proses yang terus menerus dan dilaksanakan tiap saat. Pendidikan karakter berkaitan dengan waktu yang panjang sehingga tidak dapat dilakukan dengan satu kegiatan saja.Di sinilah pentingnya pendidikan karakter. Pendidikan karakter harus diimplementasikan kemudian di integrasikan dalam kehidupan sekolah, baik dalam konteks pembelajaran di dalam kelas maupun luar kelas (Heri Gunawan, 2012: 46).

Budi pekerti adiluhung, perilaku santun, dan relegiusitas yang selama ini dijunjung tinggi sekaligus menjadi tradisi bangsa Indonesia menjadi semakin langka ditemui di tengah-tengah masyarakat, maka pendidikan karakter menjadi salah satu alternatif untuk menjawab problematika tersebut sementara lembaga pendidikan (sekolah) diharapkan dapat menjadi tempat yang mampu mewujudkan misi dari pendidikan karakter tersebut, antara lain dengan cara mengoptimalkan pembelajaran materi Pendidikan Agama Islam.

Pendidikan Agama Islam harus mampu menjadikan manusia memiliki watak tangguh berupaya memiliki iman, takwa, dan tentunya akhlak mulia dalam berprilaku, kriteria manusia terdapat akhlak mulia berupa etika, budi pekerti, atau moral sebagai wujud dari nilai-nilai pendidikan (Permendiknas, 2006: 2). Manusia juga bisa tangguh dalam menghadapi tantangan- tantangan, hambatanhambatan, dan perubahan- perubahan yang melekat dalam sesama masyarakat baik ruang tingkat lokal, nasional, regional maupun global secara keseluruhan.

\section{Metode Penelitian}

Penulis dalam memberikan jawaban sesuai dengan fokus penelitian melalui metode kualitatif dengan kajian dokumen.Kajian dokumen dianggap sebagai analisis dokumen, yang terdiri buku, artikel, internet dan bahan-bahan yang sesuai dengan penelitian.Adapun cara-cara dalam pengumpulan datanya. Pertama, melalui kajian kepustakaan yang sesuai dengan bahan yang akan diteliti. Kedua, setelah datadata telah diperoleh oleh peneliti, maka selanjutnya menganalisis datanya melalui metode deskriptif sesuai dengan pemahaman penulis dalam melakukan kajian ini (Long, 2016). 


\section{Pembahasan}

\section{Mengenal Pendidikan Karakter}

"Karakter" berasal dari bahasa latin yang berarti dipahat (Mark Rutland, 2009: 3). Hakekat karakter menurut Simon Philips, karakter ialah kumpulan nilai-nilai menuju pada suatu sistem, bisa melandasi pemikiran, sikap dan perilaku yang ditampilkan. Sedangkan Doni Koesoema, memahami bahwa karakter sama dengan kepribadian. Kepribadian dianggap sebagai cirri atau karakteristik atau gaya atau sifat khas dari diri seseorang yang bersumber dari bentukan-bentukan yang diterima dari lingkungan. Sementara Winnie, memahami bahwa istilah karakter memiliki dua pengertian. Pertama, ia menunjukkan bagaimana seseorang bertingkah laku. Apabila seseorang berperilaku tidak jujur, kejam atau rakus, tentulah orang tersebut memanifestasikan perilaku buruk.Sebaliknya, apabila seorang terdapat perilaku jujur, suka menolong, tentulah orang tersebut memanifestasikan karakter mulia.Kedua, apabila karakter erat keitannya dengan "personality".Seorang baru bisa dikategori orang yang berkarakter (a person of character) apabila sudah ada tingkah laku sesuai kaidah moral atau ketentuan baik.

Pendidikan hakikatnya usaha menyadarkan dan sangat direncanakan untuk bias mengolah suasana belajar dan kegiatan pembelajaran agar peserta didik secara aktif mengembangkan potensi dalam dirinya dengan memiliki kekuatan spiritual, pengendalian diri, kepribadian, kecerdasan, akhlak mulia, serta keterampilan yang diperlukan dirinya, masyarakat, bangsa dan negara. Pendidikan nasional bertujuan untuk menjadikan potensi peserta didik unggul serta menjadi manusia taat dan bertakwa kepada Tuhan Yang Maha Esa, ada akhlak mulia, cakap, kreatif, mandiri dan warga negara yang demokratis (Anas Salahudin, 2013: 41).

Karakter menurut Alwisol diwujudkan melalui gambaran tingkah laku dengan menonjolkan nilai benar-salah, baik-buruk, baik secara eksplisit maupun implisit (Alwisol, 2006: 8).Cakupan dalam undang-undang Nomor 20 tahun 2003 tentang sistem pendidikan nasional sebenarnya pendidikan karakter menempati posisi yang penting, hal ini dapat kita lihat dari tujuan pendidikan nasional yang menyatakan tentang pendidikan nasional memiliki fungsi pengembangan kemampuan dan cara membentuk peradaban bangsa bermartabat dalam rangka mencetak kehidupan bangsa terbaik, bertujuan untuk pengembangan potensi peserta didik menjadi 
manusia yang bermoral dan taat kepada Tuhan yang maha esa, didampingi akhlak mulia, mandiri, dan menjadi warga negara yang demokratis serta bertanggung jawab (Undang-Undang, 2003: 8).

Pendidikan karakter bukanlah semata konsep teori yang hanya ditulis di atas kertas dan dihafalkan tetapi pendidikan karakter merupakan sebuah pembelajaran yang teraplikasi dalam semua aktifitas, baik di sekolah, di tengah-tengah masyarakat dan di lingkungan rumah melalui proses pembiasaan serta keteladanan, dan dilakukan secara kontinyu. Oleh karena itu keberhasilan pendidikan karakter ini tidak hanya menjadi tanggung jawab guru di sekolah tetapi juga merupakan yanggung jawab bersama antara sekolah, masyarakat dan orang tua.

\section{Pengertian Pendidikan Agama}

Pendidikan berasal dari kata "didik" yang berarti melatih atau mengajar. Sedangkan menurut istilah, pendidikan adalah usaha manusia untuk membina kepribadiannya sesuai dengan nilai-nilai di dalam masyarakat dan kebudayaan.Agama berasal dari bahasa sansekerta yang berarti tidak kacau atau teratur. Fungsi agama dapat memberi kebebasan manusia dan kekacauan yang dihadapi dalam hidupnya bahkan menjelang matinya.Menurut terminology agama adalah suatu tata kaidah yang mengatur hubungan manusia dengan yang agung.

\section{Ruang Lingkup Pendidikan Agama Islam}

Menurut Hamka pendidikan adalah proses ta'lim dan menyampaikan sebuah misi (tarbiyah) tertentu. Tarbiyah mengandung arti yang konprehensif dalam memaknai pendidikan terutama pendidikan Islam secara vertikal maupun horizontal. Prosesnya merujuk pada pemeliharaan dan pengembangan seluruh potensi (fitrah) peserta didik baik jazmaniyah maupun rohaniah.

Pendidikan karakter merupakan bagian penting bagi kehidupan manusia. Sebagai sebuah proses, ada dua asumsi yang berbeda mengenai pendidikan karakter. Pertama, ia bisa dianggap sebagai sebuah proses yang terjadi secara tidak disengaja atau berjalan secara alamiah. Misalnya, pada dasarnya manusia belajar dari peristiwa alam yang ada untuk mengembangkan kehidupannya. Kedua, pendidikan karakter bisa dianggap sebagai proses yang terjadi secara sengaja, direncanakan, didesain dan diorganisasi berdasarkan perundang- 
undangan yang dibuat. Misalnya, UU Sisdiknas yang merupakan dasar penyelenggaraan pendidikan (Fatchul Mu'in, 2011:287).

Dalam Sistem Pendidikan Nasional Kurikulum merupakan bagian dari sistem pembelajaran yang berfungsi untuk mengaplikasikan tujuan pendidikan nasional. oleh karena itu di dalam undang-undang no 20 tahun 2003 pasal 36 kurikulum di Indonesia disusun dalam kerangka peningkatan iman dan takwa, peningkatan akhlak mulia,peningkatan potensi, kecerdasan,dan minat peserta didik, keragaman potensi, daerah dan lingkungan, tuntutan pembangunan daerah dan nasional, tuntutan dunia kerja, tuntutan iptek dan seni,agama, dinamika perkembangan global, persatuan nasional dan nilai-nilai kebangsaan.

Untuk mendukung keterlaksanaan kerangka kurikulum tersebut diatas, maka dalam pasal selanjutnya (UU No. 20 tahun 2003 pasal 37) dijelaskan bahwa didalam kurikulum wajib memuat: pendidikan agama, pendidikan kewarganegaraan, bahasa, matematika, ilmu pengetahuan alam, ilmu pengetahuan sosial, seni dan budaya, pendidikan jasmani dan olahraga,ketrampilan/kejuruan, muatan local (Fatchul Mu'in, 2011:26).

Untuk menunjang pendidikan karater perlu didukung oleh pendidikan agama melalui materi peningkatkan akhlak mulia serta nilai-nilai spiritual dalam diri anak.Hal ini sekaligus menunjukkan bahwa pendidikan agama mempunyai peranan yang penting dalam melaksanakan pendidikan karakter di sekolah.

Pendidikan agama menjadi salah satu mata pelajaran wajib, mulai dari sekolah tingkat dasar, menengah hingga perguruan tinggi. Maka pihak sekolah harus mampu menyelenggarakan pendidikan agama secara optimal dengan cara mengaplikasikan nilai-nilai agama dalam lingkungan sekolah yang dilakukan oleh seluruh siswa, tenaga pendidik, karyawan, hingga kepasa sekolah. Adapun ruang lingkup pendidikan agama Islam meliputi beberapa aspek, antar lain; AlQur'an dan Hadis, Aqidah, Akhlak, Fiqih, Tarikh dan Kebudayaan Islam.

Pembentukan Karakter Anak sebagai tujuan Pendidikan dalam Islam

Dari zaman Rasulullah SAW.konsep pendidikan karakter sebenarnya telah ada, hal ini bisa dilihat dari ucapan hadits Nabi dari Abu Hurairah RA: innama buitstu li-utammima makarimal akhlaq 
Artinya: "Sesungguhnya aku diutus hanya untuk menyempurnakan keshalihan akhlak." (HR. Al-Baihaqi).

Pembahasan substansi arti dari karakter sama dengan konsep akhlak dalam Islam, keduanya membahas tentang perbuatan atau prilaku manusia. Al-Ghazali mendefinisikan akhlak sebagai"cungkapan tentang sikap jiwa yang menimbulkan perbuatanperbuatan dengan mudah dengan tidak memerlukan pertimbangan atau pemikiran terlebih dahulu" (Abidin Ibnu Rusn, 1998: 99).

Akhlak menjadi tujuan utama dalam proses pendidikan Islam, mengingat akhlak merupakan dasar bagi keseimbangan kehidupan manusia sekaligus menjadi penentu keberhasilan bagi potensi paedagogis yang lain. Ali Abdul Halim Mahmud prinsip akhlak terdiri dari empat hal ; 1) Hikmah yaitu keadaan psikis dimana seorang dapat membedakan antara hal yang benar dan yang salah;2) Syajaah yaitu kondisi psikis dimana seorang melampiaskan atau menahan potensial dari aspek emosional dibawah kendali akal; 3) Iffah yaitu mengendalikan potensial selera maupun keinginan dibawah kendali akal dan syariat; 4) 'Adl yaitu situasi psikis yang mengatur tingkat emosi dan keinginan sesuai kebutuhan disaat melepas atau melampias (Ali Abdul Halim Mahmud, 2003: 34).

Dari pendapat di atas dapat disimpulkan bahwa akhlak merupakan pilar utama dari tujuan pendidikan di dalam Islam, hal ini berbanding lurus dengan konsep perlunya diterapkannya pendidikan karakter di sekolah. Sejalan dengan hal ini Abdullah Nasih Ulwan memberikan konsep pendidikan inluentif dalam pendidikan akhlak anak yang meliputi keteladanan, adat kebiasaan, nasihat, perhatian, dan memberikan hukuman (Abdullah Nasih Ulwan, tt: 2). Tokoh pendidikan Indonesia Ki Hajar Dewantara mengatakan bahwa guru selayaknya berprinsip "ing ngarso sung tulodo ing madyo mangun karso" (didepan memberi contoh, ditengah memberikan bimbingan dan dibelakang memberikan dorongan). Keteladanan inilah salah satu metode yang seharusnya diterapkan guru dalam pembelajaran PAI.

Tujuan utama dari pembelajaran Pendidikan Agama Islam (PAI) adalah membentuk kepribadian pada diri peserta didik. Hal ini tercermin dalam sikap dan perilaku mereka sehari-hari, maka pembelajaran PAI bukan menjadi tanggung jawab guru PAI seorang diri, tetapi dibutuhkan dukungan pihak-pihak terkait, baik di lingkungan sekolah maupun di tengah masyarakat. Mulai dari kepala sekolah, seluruh guru, hingga karayawan, termasuk orang tua di 
rumah.Dengan demikian terbentuklah siswa yang berkarakter atau berakhlak mulia.

\section{Hasil dan Pembahasan}

Pendidikan semakin mengalami perubahan mengikuti transisi di segala bidang.Pendidikan yang baik menunjukkan kualitas masyarakat di daerah tersebut.Namun tingkah laku dan moral masyarakat pun ikut mengalami pergeseran.Maraknya penodaan moral salah satunya disebabkan dampak buruk pendidikan.Pendidikan agama sebagai pelopor keilmuan memiliki potensi yang besar dalam menanggulangi kemerosotan individu. Pribadi agamis akan mampu meminimalisir akibat buruk dari arus perkembangan yang sangat deras. Karakter atau sifat agamis harus dibentuk awal masa anak hingga mempermudah perjalanan hidup manusia sampai dewasa kelak.

Semakin maraknya perubahan dan penodaan moral sematamata dimulai dari kurangnya akhlak atau karakter yang bersifat agamis pada diri seseorang. Seseorang yang mampu menanamkan jiwa yang beragama dengan baik, maka ia dapat menjalani kehidupan multicultural dengan positif. Lain halnya apabila ia kurang ada karakter agamis maka gampang melakukan tindakan akhlak negatif.

Pendidikan agama adalah salah satu cabang aspek pendidikan yang mayoritas dibutuhkan oleh pribadi beragama.Ia sebagai pedoman hidup dan merupakan salah satu sarana penanaman karakter yang benar. Didalamnya terdapat contoh-contoh karakter agama yang sangat membantu tiap pribadi dalam menghadapi budaya negative. Karakter yang baik akan memudahkan pengembangan tiap individu dalam bermasyarakat.

Untuk bisa memahami peran pendidikan agama dalam mengolah watak karakter, sekurang-kurangnya wajib membahas apa itu pengertian karakter dan apa inti pendidikan agama. Yang "inti" itulah yang besar dalam pembentukan karakter. Penting juga membahas kegiatan dilakukan agar proses pendidikan agama itu bisa bergerak sesuai cara-cara pembentukan karakter.

Dalam kajian antropologi disebutkan bahwa kebudayaan (cara manusia bersikap, berfikir, dan bertindak), akan ditentukan oleh 
sesuatu yang diyakininya benar atau tidak. Jika telah menyangkut keyakinan, maka itu berarti telah menyangkut agama (dalam pengertian yang umum). Sedangkan didalam uraian diatas diketahui bahwa cara bersikap, berfikir, dan bertindak itulah inti dari karakter seseorang. Jadi, jelas bahwa agama merupakan hal yang amat berpengaruh dalam pembentukan karakter seseorang.

Dasar-dasar pendidikan agama yang telah diletakkan orang tua, menjadi tugas guru agama di lembaga pendidikan formal, dan nonformal.Para guru pendidikan agama Islam termasuk ke dalam ruang lingkup ahlikum yang berkewajiban pula menjaga mereka dari kehancuran (QS At-tahrim; 66:6).Pendidikan hakikatnya cara atau proses yang tak berkesudahan yang menentukan karakter bangsa pada masa kini dan masa datang, sehingga tercipta bangsa akan muncul sebagai bangsa berkarakter baik atau bangsa berkarakter buruk, sangat tergantung pada kualitas pendidikan yang dapat membentuk karakter anak bangsa tersebut (Ulil Amri Syafri, 2012: 25).

\section{Hubungan Pendidikan Agama dalama Pembentukan Karakter}

Jadi pendidikan agama sangat efektif dalam segi edukatif bisa mempengaruhi pembentukan karakter yang baik.Dipandang dari segi keterkaitannya, pembentukan karakter dasar seorang anak sejak dini sangat erat hubungannya dengan apa-apa yang diajarkan dalam sisi edukatif dalam materi pendidikan agama.Agama banyak memberian pengajaran yang baik dalam membentuk karakter anak, contohnya seorang anak akan bersikap santun terhadap oang yang lebih tua dibanding dia, itu karena agama sudah memberikan kita ulasan mengenai pembentukan karakter yang lebih baik.

Telah banyak bukti dan sangkaan realita yang bisa membuktikan secara nyata bahwasannya pembelajaran pendidikan agama terdapat peran besar dan mayoritas mampu mengantarkan tiap individu agamis menghadapi kesulitan- kesulitan dan problematika masalah yang ada dengan arif dan bijaksana.Pendidikan karakter pada hakikatnya merupakan pembinaan personal peserta didik secara terprogram dengan tujuan tertentu bagi lembaga pendidikan dengan menitikberatkan pembinaan ideologi agama, budaya bangsa yang unggul dan jiwa kepemimpinan, yang sekaligus membangun kekuatan dan kualitas peserta didik yang berkarakter unggul. Pendidikan karakter pada tiga komponen, yaitu sekolah, keluarga, dan masyarakat diharapkan memiliki upaya dan usaha penanaman 
dan pembudayaan nilai, sikap, dan cara berfikir, serta meningkatkan kompetensi dan integritas. Terutama dalam aspek berbasis nilai agama, budaya bangsa, kepemimpinan, ilmu pengetahuan dan teknologi serta wawasan global bagi peserta didik dan seluruh civitas dunia pendidikan, keluarga, dan masyarakat. Untuk itu, pendidikan karakter yang menjadi tanggung jawab sekolah, keluarga, dan masyarakat harus dijadikan sebagai sarana untuk penyadaran, peneguhan, pengayaan, pencerahan dan pemahaman (Anas Salahudin, 2013: 28).

\section{Simpulan}

Dari penjelasan diatas dapat disimpulkan bahwa karakteradalah kumpulan tata nilai yang menuju pada suatu sistem, yang melandasi pemikiran, sikap dan perilaku yang ditampilkan.Dan Karakter berkaitan dng kekuatan moral, berkontraksi "positif", bukan netral.Orang berkarakter adalah orang yang mempunyai kualitas moral pendidikan agama.Dengan demikian pendidikan agama sangat berperan penting dalam pembentukan moral positif untuk orangorang.

Dengan demikian, pendidikan karakter mempunyai visi senantiasa mengarahkan diri pada cetak individu dengan moral, cakap saat mengambil keputusan yang terampil dalam kegiatan-kegiatan hariannya, sekaligus bisa mengambil peran lugas untuk bangun cara pandang kebersamaan. Pendidikan karakter dimulai lingkungan keluarga dalam membentuk dasar pribadi karena lingkungan inilah sikap pertama dikenal oleh tiap orang.Lingkungan keluarga sangat berpengaruh sebagai dasar sikap pembentukan idealisme seorang.Lanjut penentunya, lingkungan tempat tinggal, lingkungan pergaulan dan sampai pada lingkungan yang ada di sekolah ataupun madrasah. 
Alwisol. 2006. Psikologi Keperibadian. Universitas Muhammadiyah Malang (UMM): Malang.

Gunawan, Heri. 2012. Pendidikan Karakter Konsep dan Implementasi. Alfabeta: Bandung.

Kesuma, Dharma, dkk. 2011. Pendidikan Karakter Kajian Teori dan Praktik di Sekolah.Remaja Rosdakarya:Bandung.

Mahmud, Ali Abdul Halim. 2003. Tarbiyah Khuluqiyah: Pembinaan Diri Menurut Konsep Nabawi.Terj.Afifudin. Media Insani: Solo.

Permendiknas No 22 Tahun 2006. Standar Isi Untuk Satuan Pendidikan Tingkat Dasar Dan Menengah.

Ridla, Muhammad Jawwad. 2011. Tiga Aliran Utama Teori Pendidikan Islam Perspektif Sosiologis-Filosofis, Terj. Mahmud Arif. Tiara Wacana:Yogyakarta.

Sudrajat, Ajat. Mengapa Pendidikan Karakter?,Jurnal Pendidikan Karakter, Vol. 1, No. 1Universitas PGRI Semarang.

Rusn, Abidin Ibnu. 1998. Pemikiran Al-Ghazali Tentang Pendidikan. Pustaka Pelajar:Yogyakarta.

Salahudin, Anas. 2013. Pendidikan Karakter Pendidikan Berbasis Agama dan Budaya Bangsa.Bandung : CV. Pustaka Setia.

Syafri, Ulil Amri MA. 2012. Pendidikan Karakter Berbasis AlQur'an. Raja Grafindo Persada: Jakarta.

Suwito. 2004. Filsafat Pendidikan Akhlak Ibn Miskawaih. Belukar:Yogyakarta.

Ulwan, Abdullah Nasih. tt. Pedoman Pendidikan Anak Dalam Islam,Terj. Sefullah Kamalie Dan Hery Noer Ali. AsySyifa:Semarang. 
Undang-Undang No. 20 Tahun 2003.Tentang Sistem Pendidikan Nasional. 